\title{
Improvement of wine volatile composition through foliar nitrogen applications to 'Cabernet Sauvignon' grapevines in a warm climate
}

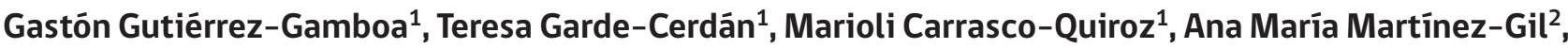 \\ and Yerko Moreno-Simunovic ${ }^{3^{*}}$
}

${ }^{1}$ Instituto de Ciencias de la Vid y del Vino (CSIC-CAR-UR), Carretera de Burgos km 6, 26007 Logroño, España.

${ }^{2}$ Universidad de Valladolid, Departamento de Química Analítica, Avda. de Madrid 50, 34004 Palencia, España.

${ }^{3}$ Universidad de Talca, Facultad de Ciencias Agrarias, Av. Lircay S/N, Talca, Chile..'Corresponding author (ymoreno@utalca.cl).

Received: 14 November 2017; Accepted: 26 January 2018; doi:10.4067/S0718-58392018000200216

\begin{abstract}
Volatile compounds play a key role on wine quality due to their importance in wine aroma. The improvement of these compounds in Cabernet Sauvignon wines may be of oenological relevance because these are usually defined by strong character and somewhat herbaceous. The effect of different foliar N applications on 'Cabernet Sauvignon' grapevines (Vitis vinifera L.) was studied in order to improve wine volatile composition. Five treatments were applied: urea (Ur), urea plus sulfur (Ur+S), arginine (Arg), and two commercial products: Nutrimyr Thiols (NT) and Basfoliar Algae (BA). Volatile compounds were analyzed by GC-MS. Results showed that wines elaborated with grapes treated with arginine (Arg) exhibited the lowest content of total higher alcohols (322.29 mg L-1). Wine concentrations of ethyl hexanoate, octanoate, and decanoate from Ur+S and BA treatments were the highest $(385.28,590.46,214.14$, and 416.00, 600.50, $227.96 \mu \mathrm{g} \mathrm{L}{ }^{-1}$, respectively). No effects were found on vanillin derivatives content in wines by foliar treatments. Total terpenes content in wines from $\mathrm{Ur}$ and Arg grapevine treatments were higher than in control (17.87 and $20.36 \mu \mathrm{g} \mathrm{L}{ }^{-1}$ than $\left.14.99 \mu \mathrm{g} \mathrm{L}^{-1}\right)$. Thus, $\mathrm{N}$ foliar applications can improve wine volatile composition, mainly by $\mathrm{Ur}+\mathrm{S}$ and BA treatments. The importance of this study is to add knowledge about the effects of foliar $\mathrm{N}$ applications on Cabernet Sauvignon wine volatile composition in warm climates.
\end{abstract}

Key words: Cabernet Sauvignon, esters, foliar application, grapevines, Vitis vinifera, volatile compounds.

\section{INTRODUCTION}

Cabernet Sauvignon is one of the most important grapevine varieties cultivated worldwide. It is originally from Bordeaux (France), but currently, it is planted in vineyards of different regions. It has been essential in countries of the "New World". Wines from 'Cabernet Sauvignon' grapevines have been awarded in various competitions worldwide, which has allowed these countries to position themselves in the world wine market. The aroma that has been usually described for this variety is fruity or floral with roasted, wood-smoke, cooked meat nuances, red/blackberry, and usually herbaceous due to its important levels of methoxypyrazines (Tao et al., 2008; Cai et al., 2014). However, the rise of temperatures and the decrease of precipitations due to climate change trigger advanced maturation. This will affect grape composition, in particular with respect to its aroma composition (van Leeuwen and Darriet, 2016). Due to this, it has shown that some viticultural practices such as defoliation or foliar $\mathrm{N}$ applications can improve aromatic composition in grapes or wines (Ancín-Azpilicueta et al., 2013; Pascual et al., 2017). 
One of the main factors that determine wine quality is aroma. Thus, several volatile compounds have been found in wines with a wide concentration range (Cai et al., 2014). These compounds belong to a various chemical family of volatiles such as higher alcohols, C6 compounds, ethyl esters, acetate esters, terpenes, among others, which contribute to the desirable wine aroma. As reviewed by Bell and Henschke (2005), N compounds contribute to the formation of some of these volatile compounds, especially higher alcohols and ethyl esters during alcoholic fermentation and regulate the formation of other volatiles, such as hydrogen sulfide or thiols. In addition, Martínez-Gil et al. (2012) presented a close correlation between the synthesis of ethyl esters during alcoholic fermentation and the must amino acid content. Thus, must $\mathrm{N}$ composition affects yeast growth and fermentation processes, which is involved in the final quality of wine, especially in the aroma (Garde-Cerdán and Ancín-Azpilicueta, 2008). In order to improve must $\mathrm{N}$ composition, different studies have been carried out applying $\mathrm{N}$ to the vineyard. However, a high rate of $\mathrm{N}$ fertilization can result in the accumulation of negative compounds in wine, such as biogenic amines and ethyl carbamate (Smit et al., 2014). A traditional way to improve wine volatile composition has been the soil $\mathrm{N}$ fertilization. However, the results exposed by different authors are quite varied. Linsenmeier et al. (2005) reported that the synthesis of wine volatile compounds was slightly affected by soil $\mathrm{N}$ fertilization. On the other hand, Webster et al. (1993) showed that, as $\mathrm{N}$ soil fertilization increased, wine concentrations of isoamyl alcohols (3-methylbutan-1-ol and 2-methylbutan-1-ol), and 2-phenylethan-1-ol decreased. In contrast, wine concentrations of butan-1-ol, (E)-hex-3-en-1-ol, phenylmethanol, and the majority of ethyl esters increased. Another innovative strategy, used in recent years, is to increase $\mathrm{N}$ vine status by foliar $\mathrm{N}$ applications. This technique allows a quick and efficient assimilation of applied products by the plants (Lasa et al., 2012). Previous studies have shown that urea foliar application improved wine volatile composition (Lacroux et al., 2008; Ancín-Azpilicueta et al., 2013). This $\mathrm{N}$ source is of low price and easily assimilated by the plants, compared to urea soil applications (Lasa et al., 2012). On the other hand, $\mathrm{N}$ application with sulfur facilitates their assimilation in grains (Tea et al., 2007). Due to this, urea plus $\mathrm{S}$ application was performed in grapevines, which improved the concentration of amino acids in 'Cabernet Sauvignon' grapes (Gutiérrez-Gamboa et al., 2017a).

Due to the aforementioned, some amino acids were applied to the grapevines in order to improve grape quality. GardeCerdán et al. (2014) reported that the use of phenylalanine increased the concentration of some amino acids compared to control samples. To our knowledge, only one study researched the effect of arginine as a new fertilizer. In a recent report, Gutiérrez-Gamboa et al. (2017a) exhibited slight differences in the must concentration of amino acids by arginine foliar application. However, the concentration of glutathione in the must was increased considerably regarding control samples. The function of this molecule in winemaking processes is to act as an antioxidant, preventing the appearance of browning pigments in musts and protecting anthocyanins from oxidation (Gambuti et al., 2015). In addition, in relation to wine volatile compounds, glutathione also exerts a protective effect in their concentration (Ugliano et al., 2011) but until now, there had been no studies in the literature reporting the effects of arginine foliar applications on wine volatile concentration.

For these reasons, the aim of this work was to study the influence of foliar application of urea, urea plus S, arginine, and two commercials $\mathrm{N}$ fertilizers to 'Cabernet Sauvignon' grapevines on wine volatile composition.

\section{MATERIALS AND METHODS}

\section{Study site}

The field study was conducted at a commercial vineyard located in a warm climate location of the Maule Valley (Pencahue, $35^{\circ} 20^{\prime}$ S , $71^{\circ} 46^{\prime}$ W; $87 \mathrm{~m}$ a.s.l.), Chile, during the 2015 growing season. A 4-yr-old 'Cabernet Sauvignon' vineyard, grown in 1103 Paulsen rootstock, trained to a vertically shoot positioned system $(2.3 \times 1.0 \mathrm{~m})$ with a plant density of 4347 plants ha ${ }^{-1}$ was used. The vineyard was equipped with a drip irrigation system using $4 \mathrm{~L} \mathrm{~h}^{-1}$ drippers, to assure the plant water needs. The vines were irrigated when the midday leaf water potential $\left(\psi_{1}\right)$ reached 1.0 to $1.2 \mathrm{MPa}$. The vineyard plot was homogeneous on its vegetative expression and fruit load. The annual average temperature was $14.5^{\circ} \mathrm{C}$ with a minimum of $-2.5^{\circ} \mathrm{C}$ (July) and a maximum of $36.7^{\circ} \mathrm{C}$ (January), and an average annual rainfall of $583.8 \mathrm{~mm}$. The vineyard soil is clay loam classified as Cunculén series Vertic Haploxeralfs (CIREN, 1997). 


\section{Grapevines treatments}

Five treatments were carried out using several N sources according to Gutiérrez-Gamboa et al. (2017a): urea (Ur), urea plus $\mathrm{S}(\mathrm{Ur}+\mathrm{S})$, arginine (Arg), and two commercial products, Nutrimyr Thiols (NT) (Italpollina Spa, Casalmenini, Italy) and Basfoliar Algae (BA) (Compo Agro, Santiago, Chile). Treatments were made in triplicate and were distributed as a complete randomized block design. Each replicate was carried out on 20 vines, so 60 plants were used for each treatment, leaving 18 untreated plants in the same row and two rows between replicates to avoid contamination. Treatments consisted of a $2 \mathrm{~kg} \mathrm{~N} \mathrm{ha}^{-1}$ dose, divided in two moments, the first at the beginning of veraison and the second $2 \mathrm{wk}$ later. In the Ur+S treatment besides the urea $\mathrm{N}, 0.5 \mathrm{~kg} \mathrm{~S}^{-1}$ for each application were added; $200 \mathrm{~mL}$ of each formulation were applied evenly per plant by spraying over the full canopy. Additionally, 60 plants, distributed in the same form, were kept as untreated control.

\section{Commercial products $\mathrm{N}$ content}

Basfoliar Algae is a concentrated extract of Chilean natural algae (Durvillaea antarctica), supplemented with several nutrients, minerals and phytohormones (auxins and cytokinins). On the other hand, Nutrimyr Thiols is a foliar fertilizer, which is sold as a wine flavor enhancer that improves grape quality. The nutritional content of both products is Basfoliar Algae (BA): $6.9 \%$ total $\mathrm{N}$ content, of which $0.9 \%$ is from the following amino acids $\left(\mathrm{g} \mathrm{L}^{-1}\right): 0.76$ alanine, 1.31 glycine, 0.51 valine, 0.29 threonine, 0.35 serine, 0.73 leucine, 0.34 isoleucine, 0.69 proline, 0.06 cysteine, 0.54 histidine, 0.23 methionine, 0.69 aspartate, 0.45 phenylalanine, 0.93 glutamate, 0.57 lysine, 0.30 tyrosine, 0.38 arginine, and 0.09 histidine; Nutrimyr Thiols (NT): $16 \%$ total $\mathrm{N}$ content, with $1.2 \%$ organic $\mathrm{N}$ and $14.8 \%$ ureic $\mathrm{N}$.

\section{Samples and winemaking}

Harvest was carried out when grapes reached their optimal technological maturity, when the weight of 200 berries remained constant, the concentration of soluble solids was around $24-25^{\circ} \mathrm{Brix}$, and the titratable acidity remained between 5 and $6 \mathrm{~g} \mathrm{~L}^{-1}$. Following the harvest, grapes were stored $1 \mathrm{~d}$ in a cold chamber at $6{ }^{\circ} \mathrm{C}$ before processing and then were destemmed and crushed to obtain the must. The winemaking process was performed according to Gutiérrez-Gamboa et al. (2017b). Each replicate was introduced into $20 \mathrm{~L}$ tanks, so 18 tanks were filled (three tanks for each treatment and three for control wine). Tanks were stored at $6{ }^{\circ} \mathrm{C}$ for pre-fermentative maceration during $2 \mathrm{~d}$. Subsequently, must was inoculated with a commercial yeast Saccharomyces cerevisiae strain BO 213 (Laffort, Bordeaux, France) to carry out the alcoholic fermentation, which took place at $22 \pm 1{ }^{\circ} \mathrm{C}$. Alcoholic fermentation was considered finished when the must reached $2.5 \mathrm{~g} \mathrm{~L}^{-1}$ residual sugar. After $16 \mathrm{~d}$ maceration-fermentation, skins and seeds were manually removed, and then the tanks were carried to cold at $6{ }^{\circ} \mathrm{C}$ to eliminate lees. Wines were inoculated with $4 \mathrm{~g} \mathrm{hL}^{-1}$ of Oenococcus oeni strain, B28 PreAc (Laffort). The malolactic fermentation was carried out in $5 \mathrm{~L}$ tanks. Malic acid analyses were performed weekly to determine the end of malolactic fermentation (bellow $100 \mathrm{mg} \mathrm{L}^{-1}$ malic acid). Then, wine samples were frozen at $-20{ }^{\circ} \mathrm{C}$ until the analysis of oenological parameters and volatile compounds.

\section{Oenological parameter analysis}

Alcohol degree, $\mathrm{pH}$, total acidity ( $\mathrm{g} \mathrm{L}^{-1}$ tartaric acid) and volatile acidity $\left(\mathrm{g} \mathrm{L}^{-1}\right.$ acetic acid), total and free sulfur dioxide and reducing sugars were analyzed according to the methodology established by OIV (2003). Wine color intensity and total polyphenol index were analyzed according to the methodology published by Bordeu and Scarpa (1998). Malic acid was analyzed weekly by an enzymatic equipment (Biowine 300, Biolan, Bilbao, Spain). All treatments were performed in triplicate, so the results were the average of three analyses $(n=3)$.

\section{Analysis of wine volatile compounds by GC-MS}

Volatile compounds were extracted following a previously reported methodology (López et al., 2002). Prepacked cartridges (total volume $3 \mathrm{~mL}$ ) filled with $200 \mathrm{mg}$ LiChrolut EN resin (Merck, Darmstadt, Germany) were used for this extraction. Before passing the wine through the cartridge, $500 \mu \mathrm{L}$ internal standard (2-octanol) were added in absolute ethanol solution (Merck). The separation, identification and quantification of volatile compounds from the wine were carried out using an Agilent 7890A gas chromatograph, coupled with a 5975C mass spectrometer (Agilent Technologies Inc., Santa Clara, California, USA). The unit was equipped with a fused silica capillary column $(30 \mathrm{~m} \times 0.25 \mathrm{~mm}$ id, and 
$0.5 \mu \mathrm{m}$ phase thickness, DB-Wax, J \& W Scientific, Agilent). The carrier was helium applied at a flow rate of $1 \mathrm{~mL} \mathrm{~min}^{-1}$. The temperature of the injector was $250{ }^{\circ} \mathrm{C}$ and $2 \mu \mathrm{L}$ wine extract were injected. The oven temperature was initially held at $40{ }^{\circ} \mathrm{C}$ for $5 \mathrm{~min}$, then increased linearly at a rate of $2{ }^{\circ} \mathrm{C} \min ^{-1}$ up to $130{ }^{\circ} \mathrm{C}$ and held at that temperature for $5 \mathrm{~min}$; after that, temperature was again increased at a rate of $2{ }^{\circ} \mathrm{C} \mathrm{min}^{-1}$ up to $180{ }^{\circ} \mathrm{C}$ and held at that temperature for $2 \mathrm{~min}$; finally, the temperature was increased linearly at a rate of $4{ }^{\circ} \mathrm{C} \mathrm{min}^{-1}$ up to $230 \mathrm{~min}$. The analysis was carried out with two injections: in split mode (50:1) for isoamyl alcohols, benzyl alcohol, 2-phenylethanol, 1-hexanol, ethyl hexanoate, ethyl lactate, diethyl succinate and ethyl octanoate, and in splitless mode for the rest of the analyzed volatile compounds. Ionization was carried out by electron impact at $70 \mathrm{eV}$. The operating method was a scan mode at $\mathrm{m} / \mathrm{z}$ between 30 and 300. Identification was carried out using the NIST library (Merck, Darmstadt, Germany). When standards were available, the quantification was based on seven-point calibration curves of the respective standards (Sigma-Aldrich, Steinheim, Germany) $\left(\mathrm{R}^{2}>0.93\right)$ in a $12 \%\left(\mathrm{v} \mathrm{v}^{-1}\right)$ ethanol solution with $6 \mathrm{~g} \mathrm{~L}^{-1}$ tartaric acid at $\mathrm{pH} 3.6$; otherwise, semi-quantitative analyses were carried out using the calibration curves of the most similar compound.

\section{Statistical analysis}

The statistical analysis of oenological parameters and volatile compounds was performed using one-way ANOVA by Statgraphics Centurion XVI.I (Statgraphics Technologies, The Plains, Virginia, USA). The Duncan test at 95\% probability level was used to compare differences between samples. Principal component analysis (PCA) was performed using InfoStat (www.infostat.com.ar).

\section{RESULTS AND DISCUSSION}

\section{Wine oenological parameters}

Table 1 shows the values of oenological parameters, color intensity (CI) and total polyphenol index (TPI) in Cabernet Sauvignon wines elaborated from grapevines untreated (control) and treated with different $\mathrm{N}$ sources: urea (Ur), urea plus S (Ur+S), arginine (Arg), Nutrymir Thiols (NT) and Basfoliar Algae (BA). Significant differences were found in $\mathrm{pH}$, total acidity, volatile acidity, and $\mathrm{CI}$ among the treatments. Regarding $\mathrm{pH}$, wines from Ur applications presented the lowest values (Table 1). The wines from Ur+S and Arg treatments showed lower total acidity than control and Ur wines. The wines made from grapevines treated with NT presented lower volatile acidity than Arg wines, and along with BA, higher values of $\mathrm{CI}$ than $\mathrm{Ur}$ and $\mathrm{Ur}+\mathrm{S}$ wines. As several authors have extensively studied, $\mathrm{pH}$ plays an important role in wine color, especially in phenolic stability and the process of copigmentation (Zhang et al., 2016). In wines, the phenolic compounds have an important role in copigmentation, aging, oxygen-depleting compounds, and the bitter and a stringent feature, which are determining factors for the wine taste and character (Cetó et al., 2012). TPI in wines was similar to those showed by Cetó et al. (2012).

Table 1. Oenological parameters, color intensity (CI), and total polyphenol index (TPI) in wines from untreated (control) and treated 'Cabernet Sauvignon' grapevines with different $\mathbf{N}$ sources as foliar fertilizers: urea (Ur), urea plus $S(U r+S)$, arginine (Arg), and different commercial products Nutrimyr Thiols (NT) and Basfoliar Algae (BA).

\begin{tabular}{|c|c|c|c|c|c|c|}
\hline & Control & $\mathrm{Ur}$ & $\mathrm{Ur}+\mathrm{S}$ & Arg & NT & $\mathrm{BA}$ \\
\hline Alcohol degree, $\% \mathrm{v} \mathrm{v}^{-1}$ & $14.73 \pm 0.74 \mathrm{a}$ & $15.07 \pm 0.25 \mathrm{a}$ & $14.60 \pm 0.60 \mathrm{a}$ & $15.00 \pm 0.30 \mathrm{a}$ & $14.23 \pm 0.65 a$ & $14.27 \pm 0.31 \mathrm{a}$ \\
\hline $\mathrm{pH}$ & $4.13 \pm 0.11 b$ & $3.99 \pm 0.06 \mathrm{a}$ & $4.16 \pm 0.02 b$ & $4.21 \pm 0.08 b$ & $4.18 \pm 0.05 b$ & $4.15 \pm 0.08 b$ \\
\hline Total acidity, $\mathrm{g} \mathrm{L}^{-1}$ (a) & $3.67 \pm 0.26 b c$ & $3.83 \pm 0.08 \mathrm{c}$ & $3.42 \pm 0.06 \mathrm{a}$ & $3.41 \pm 0.06 \mathrm{a}$ & $3.46 \pm 0.11 \mathrm{ab}$ & $3.45 \pm 0.02 \mathrm{ab}$ \\
\hline Volatile acidity, $\mathrm{g} \mathrm{L}^{-1}$ (b) & $0.39 \pm 0.04 \mathrm{ab}$ & $0.40 \pm 0.03 \mathrm{ab}$ & $0.40 \pm 0.03 \mathrm{ab}$ & $0.43 \pm 0.02 b$ & $0.36 \pm 0.04 \mathrm{a}$ & $0.42 \pm 0.04 \mathrm{ab}$ \\
\hline CI & $8.22 \pm 0.95 \mathrm{ab}$ & $6.47 \pm 0.29 a$ & $6.88 \pm 0.85 a$ & $8.39 \pm 0.97 \mathrm{ab}$ & $9.57 \pm 0.91 b$ & $9.57 \pm 1.75 b$ \\
\hline TPI & $43.20 \pm 7.73 a$ & $38.27 \pm 2.16 a$ & $41.77 \pm 4.42 \mathrm{a}$ & $46.13 \pm 3.91 \mathrm{a}$ & $46.20 \pm 2.41 \mathrm{a}$ & $43.87 \pm 1.23 \mathrm{a}$ \\
\hline
\end{tabular}

All parameters are given with their standard deviation $(n=3)$. Different letters in the same row indicate significant differences among treatments $(\mathrm{p} \leq 0.05)$.

${ }^{(a)}$ As g tartaric acid $\mathrm{L}^{-1}$

${ }^{\text {(b) }}$ As g acetic acid $\mathrm{L}^{-1}$. 
The differences obtained may be attributed to the $\mathrm{N}$ treatment applied to the grapevines since the variety studied, application dosage, climate condition, among others parameters, were similar. Lacroux et al. (2008) found few differences in most of oenological parameters studied in wines from 'Sauvignon blanc' grapevines treated with Ur and Ur+S with a dose of $10 \mathrm{~kg} \mathrm{~N} \mathrm{ha}^{-1}$. Ancín-Azpilicueta et al. (2013) showed that urea treatments at $2 \mathrm{~kg} \mathrm{~N} \mathrm{ha}^{-1}$ to 'Tempranillo' grapevines decreased the values of wine alcohol degree and total acidity, and increased $\mathrm{pH}$ and volatile acidity in wines. When these authors applied urea to the grapevines at $4 \mathrm{~kg} \mathrm{~N}^{-1}$, these differences in wines were higher than the application of $2 \mathrm{~kg}$ $\mathrm{N}^{-1} \mathrm{a}^{-1}$, except in volatile acidity, which did not differ from the control samples. Portu et al. (2015) found that urea and phenylalanine applications to the 'Tempranillo' grapevines treated with doses of 0.9 and $1.5 \mathrm{~kg} \mathrm{~N} \mathrm{ha}^{-1}$ did not affect the wine oenological parameters in respect to control samples.

\section{Wine volatile composition}

Table 2 shows the wine volatile compounds concentration from 'Cabernet Sauvignon' grapevines untreated (control) and treated with Ur, Ur+S, arginine (Arg) and two commercial N products as Nutrimyr Thiols (NT) and Basfoliar Algae (BA). Table 3 shows the odorant activity values (OAV) of the Cabernet Sauvignon wine volatile compounds. OAV was calculated as the ratio of the concentration to the odor detection thresholds reported by different authors for each volatile compound (Guth, 1997; Culleré et al., 2004; Cai et al., 2014; Noguerol-Pato et al., 2014).

The volatile compounds found in most abundant concentration in wines were isoamyl alcohols (3-methyl-1-butanol + 2-methyl-1-butanol), 2-phenylethanol and isobutanol (Table 2). As expected, the higher alcohols were the family of compounds found in most abundant concentration in wines, ranging from $97 \%$ to $98 \%$ of total volatile composition. On the other hand, the volatile compounds found in the lowest amount in wines were geraniol, linalool, citronellol, vanillin and cis-3-hexen-1-ol. Thus, the terpenes were the group of compounds found in least abundant concentration in wines, ranging from $0.002 \%$ to $0.006 \%$ of total volatile compounds content. These results were similar to those shown by Falcao et al. (2008) in a characterization of young Cabernet Sauvignon wines from Brazil. However, the results found in our research were in discrepancy to those reported by Tao et al. (2008) in young Cabernet Sauvignon wines from China. These authors found that higher alcohols represented about of $46 \%$ of the total volatile compounds, while ethyl and acetate esters reached $51 \%$ of the total analyzed volatile compounds. Table 3 shows the odorant activity value (OAV) of each wine volatile compound analyzed. It is known that volatile compounds with OAVs higher than 1 contribute to wine aroma. However, the presence of other compounds, although exhibiting OAVs lower than $1(0.2<$ OAV < 1.0) could also contribute to the aroma of wines (Garde-Cerdán et al., 2008). The most odoriferous compounds in Cabernet Sauvignon wines were ethyl octanoate, isoamyl acetate, ethyl hexanoate, 2-phenylethanol, and ethyl butanoate; while the lowest odoriferous compounds in wines were benzyl alcohol, 1-propanol, 1-butanol, 1-pentanol, 4-methyl-1-pentanol, ethyl lactate, diethyl succinate, ethyl 3-hydroxybutanoate, and methyl vanillate. Ethyl octanoate, isoamyl acetate, ethyl hexanoate, and 2-phenylethanol are responsible for the fruity and floral sensory properties of wines (Tao et al., 2008). Regarding the family of volatile compounds, the most odoriferous was the ethyl esters, followed by higher alcohols and acetate esters. It is important to note that only two acetate esters were analyzed in wines. However, their OAVs were greater than most of the individual higher alcohols (Table 3).

\section{Effects of foliar $\mathbf{N}$ applications to 'Cabernet Sauvignon' grapevines on higher alcohols content in wines}

The applications of the different sources of $\mathrm{N}$ to 'Cabernet Sauvignon' grapevines have a differentiated effect on wine higher alcohols concentration (Table 2). Ur application had a slight effect on wine higher alcohols composition. The concentration of benzyl alcohol and 1-pentanol in wines elaborated from grapevines treated with Ur was lower than control wines although, these compounds may have no importance in the wine aroma $(\mathrm{OAV}=0)$ (Table 3). In addition, wines from Ur+S grapevine treatment showed higher concentration of isoamyl alcohols (3-methyl-1-butanol + 2-methyl1-butanol) and lower content of benzyl alcohol and 2-phenylethanol than control wines. The concentration of 2-methyl-1butanol in Ur+S samples was higher than Ur, Arg and NT wines, while the content of 2-phenylethanol in Ur+S wines was lower than Ur, NT and BA wines. Isoamyl alcohols and 2-phenylethanol strongly contribute to the alcohol, cheese, roses and honey aroma descriptors to Cabernet Sauvignon wines $(\mathrm{OAV}>1)$ (Table 3). The application of Arg to the grapevines had a detrimental effect on wine higher alcohols. The concentration of 2-methyl-1-butanol and 2-phenylethanol in wines from grapevines treated with Arg was lower than control, Ur, NT, and BA wines. Thus, total higher alcohols concentration 
Table 2. Volatile compounds in Cabernet Sauvignon wines from untreated (control) and treated grapevines with different $\mathrm{N}$ sources as foliar fertilizers: urea $(\mathrm{Ur})$, urea plus $\mathrm{S}(\mathrm{Ur}+\mathrm{S})$, arginine (Arg), and different commercial products: Nutrimyr Thiols (NT) and Basfoliar Algae (BA).

\begin{tabular}{|c|c|c|c|c|c|c|}
\hline & Control & $\mathrm{Ur}$ & $\mathrm{Ur}+\mathrm{S}$ & Arg & NT & BA \\
\hline \multicolumn{7}{|l|}{ Higher alcohols, $\mathrm{mg} \mathrm{L}^{-1}$} \\
\hline 3-Methyl-1-butanol & $126.55 \pm 22.46 \mathrm{ab}$ & $123.02 \pm 22.64 \mathrm{ab}$ & $203.43 \pm 44.98 \mathrm{c}$ & $78.32 \pm 3.74 a$ & $150.49 \pm 14.78 b c$ & $203.14 \pm 43.18 c$ \\
\hline 2-Methyl-1-butanol & $52.84 \pm 8.64 b$ & $55.42 \pm 9.11 b$ & $87.96 \pm 17.39 d$ & $33.65 \pm 1.59 a$ & $65.42 \pm 6.44 b c$ & $83.98 \pm 13.21 \mathrm{~cd}$ \\
\hline Benzyl alcohol & $1.51 \pm 0.29 \mathrm{~d}$ & $0.52 \pm 0.05 \mathrm{a}$ & $0.82 \pm 0.20 \mathrm{abc}$ & $0.73 \pm 0.11 \mathrm{ab}$ & $1.07 \pm 0.12 \mathrm{c}$ & $0.87 \pm 0.16 b c$ \\
\hline 2-Phenylethanol & $207.32 \pm 18.86 b$ & $227.47 \pm 29.33 b$ & $175.49 \pm 13.48 \mathrm{a}$ & $174.43 \pm 3.47 \mathrm{a}$ & $238.92 \pm 17.12 b$ & $211.58 \pm 5.93 b$ \\
\hline 1-Propanol & $5.84 \pm 0.70 \mathrm{ab}$ & $6.73 \pm 0.62 b$ & $6.33 \pm 0.31 b$ & $6.70 \pm 0.07 b$ & $4.89 \pm 0.63 \mathrm{a}$ & $5.83 \pm 0.78 \mathrm{ab}$ \\
\hline 1-Butanol* & $2.74 \pm 0.30 \mathrm{ab}$ & $3.22 \pm 0.52 b c$ & $2.92 \pm 0.54 \mathrm{abc}$ & $3.56 \pm 0.33 c$ & $2.42 \pm 0.27 \mathrm{a}$ & $2.66 \pm 0.15 \mathrm{ab}$ \\
\hline 1-Pentanol* & $0.32 \pm 0.02 b$ & $0.26 \pm 0.02 \mathrm{a}$ & $0.35 \pm 0.01 b$ & $0.33 \pm 0.03 b$ & $0.31 \pm 0.03 b$ & $0.35 \pm 0.02 b$ \\
\hline 4-Methyl-1-pentanol* & $0.27 \pm 0.02 \mathrm{a}$ & $0.25 \pm 0.03 \mathrm{a}$ & $0.28 \pm 0.02 \mathrm{a}$ & $0.26 \pm 0.00 \mathrm{a}$ & $0.26 \pm 0.02 \mathrm{a}$ & $0.28 \pm 0.02 \mathrm{a}$ \\
\hline 3-Methyl-1-pentanol * & $0.65 \pm 0.03 \mathrm{a}$ & $0.77 \pm 0.08 \mathrm{a}$ & $0.66 \pm 0.08 \mathrm{a}$ & $0.77 \pm 0.05 \mathrm{a}$ & $0.67 \pm 0.04 \mathrm{a}$ & $0.64 \pm 0.11 \mathrm{a}$ \\
\hline Isobutanol & $24.52 \pm 2.23 \mathrm{c}$ & $25.22 \pm 0.41 c$ & $24.13 \pm 0.46 b c$ & $23.54 \pm 1.27 \mathrm{bc}$ & $18.78 \pm 1.31 \mathrm{a}$ & $21.79 \pm 1.69 b$ \\
\hline Total alcohols & $422.57 \pm 53.57 b$ & $442.88 \pm 62.80 b$ & $502.38 \pm 77.47 b$ & $322.29 \pm 10.66 a$ & $483.22 \pm 40.76 b$ & $531.19 \pm 65.25 b$ \\
\hline \multicolumn{7}{|l|}{ C6 compounds, $\mu g \mathrm{~L}^{-1}$} \\
\hline 1-Hexanol & $1633.13 \pm 234.01 \mathrm{ab}$ & $1545.76 \pm 198.90 \mathrm{ab}$ & $1839.62 \pm 36.91 \mathrm{abc}$ & $1477.46 \pm 102.45 \mathrm{a}$ & $1881.77 \pm 112.58 b c$ & $2214.87 \pm 370.39 c$ \\
\hline trans-3-Hexen-1-ol & $51.14 \pm 5.17 \mathrm{ab}$ & $43.51 \pm 5.09 \mathrm{a}$ & $50.55 \pm 2.51 \mathrm{ab}$ & $52.68 \pm 6.94 \mathrm{ab}$ & $52.20 \pm 5.79 \mathrm{ab}$ & $56.12 \pm 2.02 \mathrm{~b}$ \\
\hline cis-3-Hexen-1-ol & $27.97 \pm 3.25 b$ & $14.44 \pm 0.93 \mathrm{a}$ & $26.75 \pm 6.88 b$ & $21.04 \pm 1.78 \mathrm{ab}$ & $25.02 \pm 4.99 b$ & $16.46 \pm 0.81 \mathrm{a}$ \\
\hline Total C6 compounds & $1712.24 \pm 242.43 a$ & $1603.71 \pm 204.92 \mathrm{a}$ & $1916.92 \pm 46.30 \mathrm{ab}$ & $1551.18 \pm 111.17 \mathrm{a}$ & $1958.99 \pm 123.36 \mathrm{ab}$ & $2287.45 \pm 373.22 b$ \\
\hline \multicolumn{7}{|l|}{ Ethyl esters, $\mu \mathrm{g} \mathrm{L}-1$} \\
\hline Ethyl hexanoate & $324.42 \pm 25.48 b$ & $328.60 \pm 32.85 b$ & $385.28 \pm 36.73 c$ & $254.40 \pm 25.22 \mathrm{a}$ & $386.49 \pm 15.70 \mathrm{c}$ & $416.00 \pm 15.49 \mathrm{c}$ \\
\hline Ethyl lactate* & $2343.09 \pm 104.09 \mathrm{c}$ & $1504.66 \pm 240.34 b$ & $1575.97 \pm 315.80 \mathrm{~b}$ & $1091.91 \pm 36.71 \mathrm{a}$ & $1365.45 \pm 159.55 \mathrm{ab}$ & $1440.96 \pm 148.07 \mathrm{ab}$ \\
\hline Diethyl succinate & $4955.19 \pm 732.10 b$ & $2907.79 \pm 675.11 \mathrm{a}$ & $3061.86 \pm 1013.76 a$ & $4603.74 \pm 222.09 b$ & $4088.12 \pm 441.74 \mathrm{ab}$ & $3848.76 \pm 422.87 \mathrm{ab}$ \\
\hline Ethyl butanoate* & $171.54 \pm 1.64 b c$ & $161.79 \pm 7.28 b$ & $96.38 \pm 15.05 \mathrm{a}$ & $164.50 \pm 7.10 \mathrm{~b}$ & $182.69 \pm 8.18 \mathrm{c}$ & $181.48 \pm 5.58 \mathrm{c}$ \\
\hline Ethyl octanoate & $453.09 \pm 38.42 \mathrm{ab}$ & $396.37 \pm 28.81 \mathrm{a}$ & $590.46 \pm 34.37 \mathrm{c}$ & $416.33 \pm 24.50 \mathrm{a}$ & $503.88 \pm 61.78 b$ & $600.50 \pm 68.88 \mathrm{c}$ \\
\hline Ethyl 3-hydroxybutanoate* & $* 100.37 \pm 2.93 \mathrm{ab}$ & $97.22 \pm 0.29 \mathrm{a}$ & $103.46 \pm 5.26 \mathrm{ab}$ & $99.72 \pm 0.93 \mathrm{ab}$ & $103.57 \pm 5.91 \mathrm{ab}$ & $107.13 \pm 5.36 b$ \\
\hline Ethyl decanoate & $190.13 \pm 14.95 \mathrm{ab}$ & $157.06 \pm 8.33 \mathrm{a}$ & $214.14 \pm 28.98 c$ & $170.48 \pm 8.33 \mathrm{a}$ & $187.90 \pm 14.79 \mathrm{ab}$ & $227.96 \pm 38.96 c$ \\
\hline Total ethyl esters & $8537.82 \pm 919.62 b$ & $5553.49 \pm 993.00 \mathrm{a}$ & $6027.54 \pm 1449.91 \mathrm{a}$ & $6801.09 \pm 324.88 \mathrm{ab}$ & $6818.09 \pm 707.65 \mathrm{ab}$ & $6822.79 \pm 705.23 \mathrm{ab}$ \\
\hline \multicolumn{7}{|l|}{ Acetate esters, $\mu \mathrm{g} \mathrm{L}^{-1}$} \\
\hline Isoamyl acetate & $815.81 \pm 51.52 \mathrm{ab}$ & $702.73 \pm 74.89 a$ & $951.31 \pm 141.57 b$ & $661.43 \pm 58.20 \mathrm{a}$ & $1002.51 \pm 160.93 b$ & $1026.75 \pm 199.58 b$ \\
\hline 2-Phenylethyl acetate & $164.18 \pm 28.80 \mathrm{a}$ & $214.71 \pm 34.26 b$ & $147.75 \pm 23.86 a$ & $165.68 \pm 10.86 a$ & $160.17 \pm 12.17 \mathrm{a}$ & $145.86 \pm 26.31 \mathrm{a}$ \\
\hline Total acetates & $979.99 \pm 80.32 \mathrm{ab}$ & $917.44 \pm 109.16 \mathrm{ab}$ & $1099.06 \pm 165.43 \mathrm{ab}$ & $827.11 \pm 69.06 \mathrm{a}$ & $1162.68 \pm 173.09 \mathrm{~b}$ & $1172.60 \pm 225.88 b$ \\
\hline \multicolumn{7}{|l|}{ Vanillin derivatives, $\mu \mathrm{g} \mathrm{L}^{-1}$} \\
\hline Vanillin & $27.29 \pm 0.23 \mathrm{ab}$ & $26.72 \pm 0.66 \mathrm{a}$ & $28.42 \pm 0.85 \mathrm{ab}$ & $28.15 \pm 1.31 \mathrm{ab}$ & $28.77 \pm 1.43 b$ & $28.56 \pm 0.59 b$ \\
\hline Methyl vanillate & $39.73 \pm 0.72 \mathrm{a}$ & $39.21 \pm 3.58 \mathrm{a}$ & $39.07 \pm 1.22 \mathrm{a}$ & $41.30 \pm 2.33 \mathrm{a}$ & $38.57 \pm 1.31 \mathrm{a}$ & $40.11 \pm 0.56 \mathrm{a}$ \\
\hline Ethyl vanillate* & $37.59 \pm 0.99 \mathrm{ab}$ & $36.13 \pm 0.35 \mathrm{a}$ & $35.75 \pm 1.07 \mathrm{a}$ & $38.40 \pm 0.99 b$ & $38.39 \pm 1.80 b$ & $36.25 \pm 0.85 a$ \\
\hline Acetovanillone & $58.87 \pm 4.11 \mathrm{a}$ & $50.84 \pm 6.34 \mathrm{a}$ & $55.61 \pm 6.21 \mathrm{a}$ & $56.73 \pm 7.15 \mathrm{a}$ & $52.78 \pm 1.34 \mathrm{a}$ & $56.02 \pm 8.24 \mathrm{a}$ \\
\hline Total vanillin derivatives & $163.47 \pm 6.05 \mathrm{a}$ & $152.90 \pm 10.93 \mathrm{a}$ & $158.84 \pm 9.36 \mathrm{a}$ & $164.58 \pm 11.77 \mathrm{a}$ & $158.51 \pm 5.88 \mathrm{a}$ & $160.94 \pm 10.23 \mathrm{a}$ \\
\hline \multicolumn{7}{|c|}{ Terpenes, $\mu \mathrm{g} \mathrm{L^{-1 }}$} \\
\hline Geraniol & $3.32 \pm 0.10 \mathrm{a}$ & $3.35 \pm 0.35 \mathrm{ab}$ & $3.89 \pm 0.11 \mathrm{c}$ & $3.60 \pm 0.07 \mathrm{abc}$ & $3.82 \pm 0.10 \mathrm{c}$ & $3.76 \pm 0.38 b c$ \\
\hline Linalool & $3.38 \pm 0.23 \mathrm{a}$ & $6.42 \pm 0.09 \mathrm{~d}$ & $3.93 \pm 0.02 \mathrm{ab}$ & $5.12 \pm 0.82 \mathrm{c}$ & $3.72 \pm 0.44 \mathrm{ab}$ & $4.26 \pm 0.55 b$ \\
\hline Citronellol & $8.29 \pm 1.47 \mathrm{~b}$ & $8.10 \pm 0.56 b$ & $6.51 \pm 0.62 \mathrm{a}$ & $11.64 \pm 0.04 \mathrm{c}$ & $8.74 \pm 0.66 b$ & $8.09 \pm 0.38 b$ \\
\hline Total terpenes & $14.99 \pm 1.80 \mathrm{a}$ & $17.87 \pm 1.01 \mathrm{~b}$ & $14.33 \pm 0.75 \mathrm{a}$ & $20.36 \pm 0.93 c$ & $16.29 \pm 1.20 \mathrm{ab}$ & $16.11 \pm 1.32 \mathrm{ab}$ \\
\hline
\end{tabular}

All parameters are given with their standard deviation $(n=3)$. Different letters in the same row indicate significant differences among treatments $(\mathrm{p} \leq 0.05)$.

*Semi-quantitative analyses were carried out using the calibration curves of the most similar compound.

in wines from Arg grapevine treatment was the lowest. NT applied to the grapevines had a slight effect on wine higher alcohols. The concentration of benzyl alcohol and isobutanol in wines from grapevines treated with NT was lower than control wines (Table 2). The application of BA improved the concentration of certain individual higher alcohols, especially compounds that contribute to wine aroma. Thus, the concentration of isoamyl alcohols in wines elaborated from grapes treated with BA was higher than control, Ur, and Arg wines, while the concentration of benzyl alcohol and isobutanol was lower than control wines.

In our samples, must yeast assimilable $\mathrm{N}$ (YAN) concentrations ranged from 251 to $282 \mathrm{mg} \mathrm{N} \mathrm{L}^{-1}$ (GutiérrezGamboa et al., 2017a). These values are considered as moderate N levels (Bell and Henschke, 2005). Ur, Arg, and NT treatments applied to the grapevines increased must YAN concentration respect to the control samples; however, the foliar application of Ur+S and BA treatments did not affect must YAN content (Gutiérrez-Gamboa et al., 2017a). AncínAzpilicueta et al. (2013) and Lasa et al. (2012) found an inverse correlation between the concentration of wine higher 
Table 3. Odorant activity value (OAV) of the different volatile compounds found in Cabernet Sauvignon wines from untreated (control) and treated grapevines with different $\mathbf{N}$ sources as foliar fertilizer: urea (Ur), urea plus $S(U r+S)$, arginine (Arg), and different commercial products: Nutrimyr Thiols (NT) and Basfoliar Algae (BA).

\begin{tabular}{|c|c|c|c|c|c|c|c|c|}
\hline & Control & $\mathrm{Ur}$ & $\mathrm{Ur}+\mathrm{S}$ & Arg & NT & $\mathrm{BA}$ & Odor threshold & Aroma descriptor \\
\hline \multicolumn{9}{|l|}{ Higher alcohols } \\
\hline 3-Methyl-1-butanol & 4.22 & 4.10 & 6.78 & 2.61 & 5.02 & 6.77 & $30000^{\mathrm{d}}$ & Cheese, alcohol ${ }^{\text {bd }}$ \\
\hline 2-Methyl-1-butanol & 1.76 & 1.85 & 2.93 & 1.12 & 2.18 & 2.80 & $30000^{\mathrm{d}}$ & Alcohol $^{\mathrm{d}}$ \\
\hline Benzyl alcohol & 0.01 & 0.00 & 0.00 & 0.00 & 0.01 & 0.00 & $200000^{\mathrm{d}}$ & Roasted, sweet, fruity ${ }^{\mathrm{c}}$ \\
\hline 2-Phenylethanol & 20.73 & 22.75 & 17.55 & 17.44 & 23.89 & 21.16 & $10000^{\mathrm{d}}$ & Roses, honey ${ }^{\mathrm{c}}$ \\
\hline 1-Propanol & 0.02 & 0.02 & 0.02 & 0.02 & 0.02 & 0.02 & $306000^{c}$ & Alcohol, ripe fruit ${ }^{\mathrm{c}}$ \\
\hline 1-Butanol & 0.02 & 0.02 & 0.02 & 0.02 & 0.02 & 0.02 & $150000^{\mathrm{d}}$ & Medicinal, phenolic ${ }^{\mathrm{c}}$ \\
\hline 1-Pentanol & 0.00 & 0.00 & 0.01 & 0.01 & 0.00 & 0.01 & $64000^{c}$ & Balsamic, bitter almond ${ }^{c}$ \\
\hline 4-Methyl-1-pentanol & 0.01 & 0.01 & 0.01 & 0.01 & 0.01 & 0.01 & $50000^{c}$ & Almond, toasted ${ }^{c}$ \\
\hline 3-Methyl-1-pentanol & 1.31 & 1.54 & 1.32 & 1.53 & 1.33 & 1.28 & $500^{c}$ & Pungent, solvent, greenc ${ }^{c}$ \\
\hline Isobutanol & 0.33 & 0.34 & 0.32 & 0.31 & 0.25 & 0.29 & $75000^{c}$ & Alcohol, solvent, green, bitter ${ }^{c}$ \\
\hline \multicolumn{9}{|l|}{ C6 compounds } \\
\hline 1-Hexanol & 0.20 & 0.19 & 0.23 & 0.18 & 0.24 & 0.28 & $8000^{\mathrm{d}}$ & Herbaceous, grass, woody ${ }^{c}$ \\
\hline trans-3-Hexen-1-ol & 0.05 & 0.04 & 0.05 & 0.05 & 0.05 & 0.06 & $1000^{\mathrm{d}}$ & Herbaceous, green ${ }^{c}$ \\
\hline cis-3-Hexen-1-ol & 0.07 & 0.04 & 0.07 & 0.05 & 0.06 & 0.04 & $400^{\mathrm{d}}$ & Herbaceous, green, bitter, fatty ${ }^{\mathrm{c}}$ \\
\hline \multicolumn{9}{|l|}{ Ethyl esters } \\
\hline Ethyl hexanoate & 23.17 & 23.47 & 27.52 & 18.17 & 27.61 & 29.71 & $14^{\mathrm{b}}$ & Banana, green apple ${ }^{c}$ \\
\hline Ethyl lactate & 0.02 & 0.01 & 0.01 & 0.01 & 0.01 & 0.01 & $154636^{\mathrm{b}}$ & Fruity, buttery ${ }^{\mathrm{c}}$ \\
\hline Diethyl succinate & 0.02 & 0.01 & 0.02 & 0.02 & 0.02 & 0.02 & $200000^{\mathrm{d}}$ & Fruity, melon ${ }^{\mathrm{c}}$ \\
\hline Ethyl butanoate & 8.58 & 8.09 & 4.82 & 8.22 & 9.13 & 9.07 & $20^{\mathrm{b}}$ & Banana, pineapple, strawberry ${ }^{\mathrm{c}}$ \\
\hline Ethyl octanoate & 90.62 & 79.27 & 118.09 & 83.27 & 100.78 & 120.10 & $5^{\mathrm{b}}$ & Sweet, floral, fruity, banana, pearc \\
\hline Ethyl 3-hydroxybutanoate & 0.01 & 0.00 & 0.01 & 0.00 & 0.01 & 0.01 & $20000^{\mathrm{d}}$ & Grape $^{c}$ \\
\hline Ethyl decanoate & 0.95 & 0.79 & 1.07 & 0.85 & 0.94 & 1.14 & $200^{\mathrm{d}}$ & Fruity, fatty, pleasant ${ }^{\mathrm{c}}$ \\
\hline \multicolumn{9}{|l|}{ Acetate esters } \\
\hline Isoamy lacetate & 27.19 & 23.42 & 31.71 & 22.05 & 33.42 & 34.22 & $30^{\mathrm{a}}$ & Banana $^{c}$ \\
\hline 2-Phenylethyl acetate & 0.66 & 0.86 & 0.59 & 0.66 & 0.64 & 0.58 & $250^{\mathrm{d}}$ & Rose $^{\mathrm{d}}$ \\
\hline \multicolumn{9}{|l|}{ Vanillin derivatives } \\
\hline Vanillin & 0.45 & 0.45 & 0.47 & 0.47 & 0.48 & 0.48 & $60^{\mathrm{d}}$ & Vanillin ${ }^{\mathrm{b}}$ \\
\hline Methyl vanillate & 0.01 & 0.01 & 0.01 & 0.01 & 0.01 & 0.01 & $3000^{\mathrm{b}}$ & Vanillin ${ }^{\mathrm{b}}$ \\
\hline Ethyl vanillate & 0.04 & 0.04 & 0.04 & 0.04 & 0.04 & 0.04 & $990^{\mathrm{d}}$ & Pollen, flowery ${ }^{\mathrm{b}}$ \\
\hline Acetovanillone & 0.06 & 0.05 & 0.06 & 0.06 & 0.05 & 0.06 & $1000^{\mathrm{d}}$ & Flowery, clove, vanilla ${ }^{b}$ \\
\hline \multicolumn{9}{|l|}{ Terpenes } \\
\hline Geraniol & 0.11 & 0.11 & 0.13 & 0.12 & 0.13 & 0.13 & $30^{\mathrm{d}}$ & Citric, geranium $^{c}$ \\
\hline Linalool & 0.23 & 0.43 & 0.26 & 0.34 & 0.25 & 0.28 & $15^{\mathrm{d}}$ & Flowery, muscat ${ }^{\mathrm{c}}$ \\
\hline Citronellol & 0.08 & 0.08 & 0.07 & 0.12 & 0.09 & 0.08 & $100^{\mathrm{d}}$ & Rose, citrus $^{\text {cd }}$ \\
\hline
\end{tabular}

OAV was calculated from the odors threshold $\left(\mu \mathrm{g} \mathrm{L}^{-1}\right)$ exhibited by different authors: ${ }^{\mathrm{a}} \mathrm{Guth}(1997),{ }^{\mathrm{b}} \mathrm{Culleré}$ et al. (2004), ${ }^{\mathrm{c}} \mathrm{Cai}$ et al. (2014), and ${ }^{\mathrm{d}}$ Noguerol-Pato et al. (2014).

alcohols and YAN in must. Thus, these authors showed that the higher alcohols concentration in wines decreased as the YAN content in must increased by the effect of urea foliar applications to the grapevines. Therefore, the low wine concentration of several individual higher alcohols in Ur, Arg, and NT wines were probably due to the increase in YAN concentrations through the $\mathrm{N}$ foliar applications.

Thus, Oshita et al. (1995) reported that under low amino acid availability related to low YAN concentrations, surplus keto acids, which are largely synthesized from sugars, are decarboxylated and reduced to higher alcohols, due to the lack of alpha-amino $\mathrm{N}$ availability from transamination reactions. In contrast, under the presence of sufficient amino acids in the medium, amino acid transamination reactions (needed for the biosynthesis of amino acids in short supply) lead to a relatively larger formation of higher alcohols essentially from corresponding amino acids by the Ehrlich pathway, relative to those formed from sugars (Bell and Henschke, 2005).

\section{Effects of foliar $\mathbf{N}$ applications to 'Cabernet Sauvignon' grapevines on $\mathbf{C 6}$ compounds content in wines}

Ur and BA applications to 'Cabernet Sauvignon' grapevines had effects on the wine concentration of C6 compounds. The C6 compounds at high levels can provide undesirable herbaceous flavors to the wines (Cai et al., 2014). These descriptors are usually given to define the wine Cabernet Sauvignon aroma (Cai et al., 2014). The wine concentration of cis-3-hexen1-ol elaborated from grapes treated with Ur and BA was lower than control, Ur+S, and NT samples (Table 2). Wines 
resulting from grapes treated with BA showed higher concentration of 1-hexanol than control, Ur, and Arg wines. The concentration of total C6 compounds in wines elaborated from grapes treated with BA was higher than control, Ur and Arg wines. Regarding OAV values, the high concentration of 1-hexanol found in BA wines can affect the wine aroma $(\mathrm{OAV}>0.2)$ being able to contribute to a more herbaceous aroma in wine (Table 3). On the other hand, cis-3-hexen-1-ol did not contribute to the aroma of Cabernet Sauvignon wines $(\mathrm{OAV}<0.1)$ (Table 3).

\section{Effects of foliar $\mathbf{N}$ applications to 'Cabernet Sauvignon' grapevines on ethyl and acetate esters content in wines}

The different foliar N applications to 'Cabernet Sauvignon' grapevines have an important effect on wine ethyl and acetate esters concentrations (Table 2). The concentration of ethyl hexanoate, ethyl octanoate, and ethyl decanoate in wines from $\mathrm{Ur}+\mathrm{S}$ and BA grapevine treatments was higher than control, Ur, and Arg wines. These compounds greatly contribute to the fruity aroma of the wine with aromatic descriptors such as banana, green apple, pear, among others (Table 3). The concentration of ethyl lactate in wines elaborated from untreated grapes was the highest. This compound appears generally in relatively high amounts when lactic acid has formed in malolactic fermentation (Cortés-Diéguez et al., 2015). The wine concentration of diethyl succinate in Ur and Ur+S samples was lower than control and Arg wines. Diethyl succinate increases after the aging of the wine; however, its composition is representative of the wine distillate (Cortés-Diéguez et al., 2015). Ethyl lactate and diethyl succinate did not contribute to the Cabernet Sauvignon wine aroma (OAVs < 0.2) (Table 3). Due to the decrease in these compounds, the concentration of total ethyl esters in wines from Ur and Ur+ S treatments was lower than control wines. The application of Arg to grapevines had slight effect on wine ethyl esters concentration. Thus, the concentration of ethyl hexanoate in wines elaborated from grapes treated with Arg was the lowest. The commercial products applied to the grapevines had a differentiating effect on ethyl esters composition. The concentration of ethyl octanoate and ethyl decanoate in wines from NT grapevine treatment was lower than BA wines. The concentration of ethyl butanoate in wines from commercial products grapevine treatments (NT and BA) was higher than Ur, Ur+S, and Arg wines, contributing to the banana, pineapple, and strawberry wine aroma (Table 3) (Cai et al., 2014).

Regarding the acetate esters, the concentration of isoamyl acetate in wines from Ur+S, NT, and BA grapevine treatments was higher than Ur and Arg wines. However, there were nonsignificant differences for this compound among the treatments and control samples. This compound can contribute to banana aroma in wines (Cai et al., 2014). The concentration of 2-phenylethyl acetate in wines elaborated from grapes treated with Ur was the highest. This compound can contribute in a pleasant way to the Cabernet Sauvignon wines with roses aromas (OAV > 0.2) (Table 3). The wines from Arg treatment showed lower concentration of total acetate esters than NT and BA samples.

The principal esters of wine are synthesized enzymatically by yeast from alcohols and fatty acids, but esterases and wine acidity compete causing their hydrolysis (Bell and Henschke, 2005). Martínez-Gil et al. (2012) confirmed the possibility to estimate the concentration of ethyl esters in the wines with the concentration of $\mathrm{N}$ compounds in the must, exhibiting a strong relationship between the must $\mathrm{N}$ composition and the formation of ethyl esters in wines. In addition, Ancín-Azpilicueta et al. (2013) reported that the foliar urea application increased the concentration of ethyl hexanoate, ethyl octanoate and ethyl decanoate as the YAN concentration increases by incremental doses of urea. Regarding the grape amino acids data, Gutiérrez-Gamboa et al. (2017a) showed a strong correlation between a high concentration of several individual amino acids and the foliar applications of Ur+S and BA to the grapevines. Therefore, the highest concentration of ethyl hexanoate, ethyl octanoate and ethyl decanoate in wines from grapes treated with $\mathrm{Ur}+\mathrm{S}$ and $\mathrm{BA}$ applications were probably due to the high concentration of grape amino acid reached through of these treatments. These compounds may contribute significantly to floral and fruity aroma to the Cabernet Sauvignon wines (OAV > 1) (Table 3).

\section{Effects of foliar $\mathbf{N}$ applications to 'Cabernet Sauvignon' grapevines on vanillin derivatives and terpenes content in wines}

The different $\mathrm{N}$ foliar applications to 'Cabernet Sauvignon grapevines' did not affect the wine concentration of any vanillin derivative compounds and only vanillin could contribute to the Cabernet Sauvignon wine aroma (OAV > 0.2) (Tables 2 and 3). Terpenes play an important role on the varietal aroma of wine contributing to its floral and citric character (Peinado et al., 2004). The treatments applied to the grapevines significantly affected the wine concentration of terpenes in Cabernet Sauvignon wines (Table 2). Thus, the concentration of geraniol in wines made from grapes treated with $\mathrm{Ur}+\mathrm{S}, \mathrm{NT}$, and BA was higher than control wines. In addition, the concentration of linalool in wines elaborated from 
grapes treated with Ur was the highest. This compound can contribute to the wine with floral aromas according to the $\mathrm{OAV}$ values $(\mathrm{OAV}>0.2)$ (Table 3$)$. Moreover, the concentration of citronellol and total terpenes in wines elaborated from grapes treated with Arg was the highest.

\section{Treatments classification}

To classify the different treatments, PCA was performed (Figure 1) with the compounds, whose p-valor in the f-test was less than 0.5. Principal component 1 (PC1) explained $47.8 \%$ of the variance and principal component 2 (PC2) explained $20.5 \%$, representing a $68.3 \%$ of the total variance. PC1 was strongly correlated with isoamyl alcohols, 1-hexanol, ethyl hexanoate, ethyl octanoate, ethyl 3-hydroxybutanoate, ethyl decanoate, isoamyl acetate, and 2-phenylethyl acetate. PC2 was strongly correlated with diethyl succinate and ethyl vanillate. PC1 allowed to separate control and the different treatments. Control samples were correlated with high content of diethyl succinate, ethyl butanoate, ethyl vanillate, and citronellol in the wine. These compounds except ethyl butanoate did not contribute the wine aroma (Table 3 ). Ur treatment was correlated with high wine concentration of 1-propanol, 1-butanol, isobutanol, 2-phenylethyl acetate, and linalool. Of these compounds, only 1-butanol did not affect the wine aroma (Table 3). The Ur+S and BA treatments were correlated with major content of several volatile compounds in the wine such as isoamyl alcohols, 1-hexanol, ethyl hexanoate, ethyl octanoate, ethyl 3-hydroxybutanoate, ethyl decanoate, isoamyl acetate, and geraniol in relation to the other treatments. Of these compounds, ethyl 3-hydroxybutanoate, and geraniol did not affect the wine aroma (Table 3). The NT treatment was correlated with high content of 1-pentanol, and vanillin in the wine. The latter can contribute to the wine aroma (Table 3). Arg was inversely correlated with high content of isoamyl alcohols, ethyl hexanoate, and ethyl octanoate.

As reported by Gutiérrez-Gamboa et al. (2017a), Ur+S and BA applications to the 'Cabernet Sauvignon' grapevines were correlated with high must concentration of alanine, isoleucine, valine, and threonine. Higher alcohols are formed from these amino acids (Bell and Henschke, 2005). On the other hand, these same treatments were also correlated with high must concentration of other several amino acids which could led to an important synthesis of wine ethyl esters

Figure 1. Principal component analysis (PCA) performed with wine volatile compounds, whose p-valor in the F-test was less than 0.5, in 'Cabernet Sauvignon' samples from untreated, control (Ctr), and treated vineyards with different foliar $\mathrm{N}$ applications, such as urea (Ur), urea plus $\mathrm{S}(\mathrm{Ur}+\mathrm{S})$, arginine (Arg) and two different commercial products, Nutrimyr Thiols (NT) and Basfoliar Algae (BA).

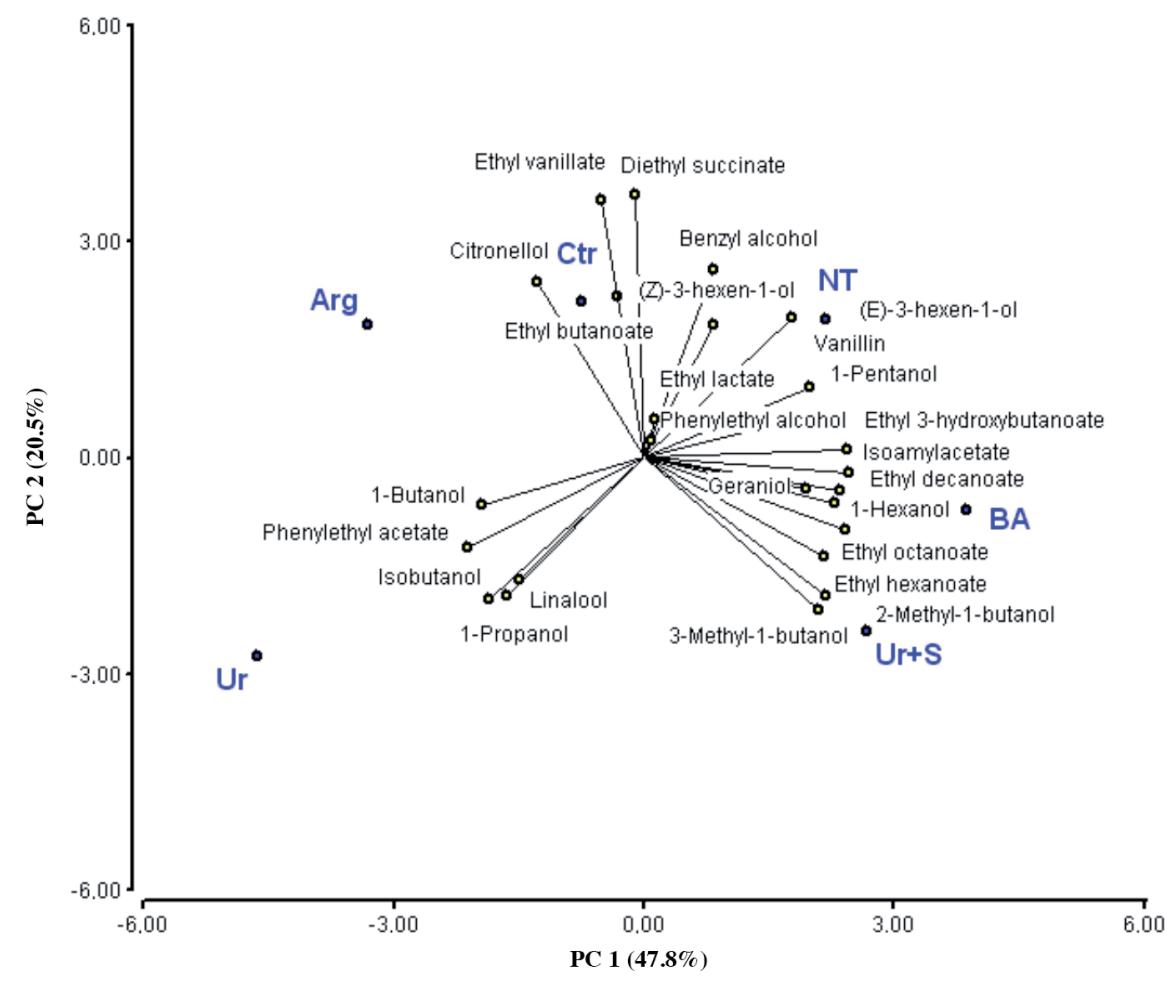


(Bell and Henschke, 2005). The addition of amino acids and ammonium nitrogen increased both acetate and medium chain fatty acid esters to a greater extent and decreased higher alcohols to a lesser extent than ammonium nitrogen alone, whereas ammonium nitrogen substantially increased ethyl acetate and acetic acid (Torrea et al., 2011). Moreover, according to the results in cachaça fermentation, higher alcohol production was reduced by ammonium supplementation, and this can be correlated with a general downregulation of genes encoding decarboxylases and dehydrogenases of the Ehrlich pathway. The production of acetate esters was enhanced by mid-range ammonium supplementation while the production of acyl esters by high ammonium supplementation. The acyl esters could be correlated with expression of alcohol acyl-transferase EEBI and the acyl esterase IAHI (Espinosa Vidal et al., 2013). Therefore, the aforementioned volatile compounds may contribute to the desirable aroma to Cabernet Sauvignon wines, which exhibited OAV values higher than 0.2. Because of this, Ur+S and BA treatments application to the 'Cabernet Sauvignon' grapevines improved wine volatile composition, respect to the others treatments and control samples.

\section{CONCLUSIONS}

Nitrogen foliar applications to 'Cabernet Sauvignon' grapevines improved wine volatile compounds concentration from a vineyard located in a warm climate, mainly those that have varietal aroma, fruity and floral descriptors. The most relevant results were achieved through urea plus S and Basfoliar Algae treatments on some higher alcohols and esters. Besides, arginine and urea applications to the grapevines allowed a high content of certain terpenes in wines. Therefore, foliar $\mathrm{N}$ applications to the 'Cabernet Sauvignon' grapevines can enhance wine aroma. These findings have oenological and viticultural interest for improving wine quality, considering the negative impact that climate change have in warmer wine regions on the Cabernet Sauvignon wine production.

\section{ACKNOWLEDGEMENTS}

We would like to thank San Pedro's commercial vineyard (Winery in the Maule Valley, Region del Maule, Pencahue, Chile) for their collaboration in this research. We are grateful for the financial support given by CONICYT, BCH/ Doctorado-72170532. We would also like to thank MINECO.

\section{REFERENCES}

Ancín-Azpilicueta, C., Nieto-Rojo, R., and Gómez-Cordón, J. 2013. Effect of foliar urea fertilisation on volatile compounds in Tempranillo wine. Journal of the Science of Food and Agriculture 93:1485-1491. doi:10.1002/jsfa.5921.

Bell, S.J., and Henschke, P.A. 2005. Implications of nitrogen nutrition for grapes, fermentation and wine. Australian Journal of Grape and Wine Research 11:242-295. doi:10.1111/j.1755-0238.2005.tb00028.x.

Bordeu, E., and Scarpa, J.A. 1998. Análisis químico del vino. Ediciones Universidad Católica de Chile, Santiago, Chile.

Cai, J., Zhu, B.Q., Wang, Y.H., Lu, L., Lan, Y.B., Reeves, M.J., et al. 2014. Influence of pre-fermentation cold maceration treatment on aroma compounds of Cabernet Sauvignon wines fermented in different industrial scale fermenters. Food Chemistry 154:217-229. doi:10.1016/j.foodchem.2014.01.003.

Cetó, X., Gutiérrez, J.M., Gutiérrez, M., Céspedes, F., Capdevilla, J., Mínguez, S., et al. 2012. Determination of total polyphenol index in wines employing a voltammetric electronic tongue. Analytica Chimica Acta 732:172-179. doi:10.1016/j. aca.2012.02.026.

CIREN. 1997. Estudio Agrológico, VII Región. Descripciones de Suelos. Materiales y Símbolos. Centro de Información de Recursos Naturales (CIREN), Santiago, Chile.

Cortés-Diéguez, S., Rodriguez-Solana, R., Domínguez, J.M., and Díaz, E. 2015. Impact odorants and sensory profile of young red wines from four Galician (NW of Spain) traditional cultivars. Journal of the Institute of Brewing 121:628-635. doi:10.1002/jib.252.

Culleré, L., Escudero, A., Cacho, J., and Ferreira, V. 2004. Gas chromatography olfactory and chemical qualitative study of the aroma of six premium quality Spanish aged red wines. Journal of Agricultural and Food Chemistry 52:1653-1660. doi:10.1021/jf0350820.

Espinosa Vidal, E., de Billerbeck, G.M., Ardaillon Simões, D., Schuler, A., François, J.M., and de Morais Jr., M.A. 2013. Influence of nitrogen supply on the production of higher alcohols/esters and expression of flavour-related genes in cachaça fermentation. Food Chemistry 138:701-708. doi:http://dx.doi.org/10.1016/j.foodchem.2012.10.147. 
Falcao, L.D., Revel, G., Perello, M.C., Riquier, L., Rosier, J.P., Auzani Uberti, A.A., et al. 2008. Volatile profile characterization of young Cabernet Sauvignon wines from a new grape growing region in Brazil. Journal International des Sciences de la Vigne et du Vin 42:133-135. doi:10.20870/oeno-one.2008.42.3.814.

Gambuti, A., Han, G., Peterson, A.L., and Waterhouse, A.L. 2015. Sulphur dioxide and glutathione alter the outcome of microoxygenation. American Journal of Enology and Viticulture 66:411-423. doi:10.5344/ajev.2015.15005.

Garde-Cerdán, T., and Ancín-Azpilicueta, C. 2008. Effect of the addition of different quantities of amino acids to nitrogendeficient must on the formation of esters, alcohols, and acids during wine alcoholic fermentation. LWT-Food Science and Technology 41:501-510. doi:10.1016/j.lwt.2007.03.018.

Garde-Cerdán, T., Jarauta, I., Salinas, M.R., and Ancín-Azpilicueta, C. 2008. Comparative study of the volatile composition in wines obtained from traditional vinification and from the Ganimede method. Journal of the Science of Food and Agriculture 88:1777-1785. doi:10.1002/jsfa.3280.

Garde-Cerdán, T., López, R., Portu, J., González-Arenzana, L., López-Alfaro, I., and Santamaría, P. 2014. Study of the effects of proline, phenylalanine, and urea foliar application to Tempranillo vineyards on grape amino acid content. Comparison with commercial nitrogen fertilisers. Food Chemistry 163:136-131. doi:10.1016/j.foodchem.2014.04.101.

Guth, H. 1997. Quantitation and sensory studies of character impact odorant of different white wine varieties. Journal of Agricultural and Food Chemistry 45:3027-3032. doi:10.1021/jf970280a.

Gutiérrez-Gamboa, G., Garde-Cerdán, T., Gonzalo-Diago, A., Moreno-Simunovic, Y., and Martínez-Gil, A.M. 2017a. Effect of different foliar nitrogen applications on the must amino acids and glutathione composition in Cabernet Sauvignon vineyard. LWT-Food Science and Technology 75:147-154. doi:10.1016/j.lwt.2016.08.039.

Gutiérrez-Gamboa, G., Garde-Cerdán, T., Portu, J., Moreno-Simunovic, Y., and Martínez-Gil, A.M. 2017b. Foliar nitrogen application in Cabernet Sauvignon vines: Effects on wine flavonoid and amino acid content. Food Research International 96:46-53. doi:10.1016/j.foodres.2017.03.025.

Lacroux, F., Tregoat, O., Van Leeuwen, C., Pons, A., Tominaga, T., Lavigne-Cruège, V., et al. 2008. Effect of foliar nitrogen and sulphur application on aromatic expression of Vitis vinifera L. cv. Sauvignon blanc. Journal International des Sciences de la Vigne et du Vin 42:125-132. doi:10.20870/oeno-one.2008.42.3.816.

Lasa, B., Menendez, S., Sagastizabal, K., Cervantes, M.E.C., Irigoyen, I., Muro, J., et al. 2012. Foliar application of urea to "Sauvignon Blanc" and "Merlot" vines: doses and time of application. Plant Growth Regulation 67:73-81. doi:10.1007/s10725-012.

Linsenmeier, A., Muno, H., Schubert, S., and Löhnertz, O. 2005. Effect of different nitrogen fertilization on aroma quality of Riesling. p. 724-730. Proceeding XIV International GESCO Viticulture Congress, Geisenheim. 23-27 August. Groupe Étude des Systémes de Conduite de la Vigne (GESCO), Geisenheim, Germany.

López, R., Aznar, M., Cacho, J., and Ferreira, V. 2002. Determination of minor and trace volatile compounds in wine by solidphase extraction and gas chromatography with mass spectrometric detection. Journal of Chromatography A 966:167-177. doi:10.1016/S0021-9673(02)00696-9.

Martínez-Gil, A.M., Garde-Cerdán, T., Lorenzo, C., Lara, J.F., Pardo, F., and Salinas, M.R. 2012. Volatile compounds formation in alcoholic fermentation from grapes collected at 2 maturation stages: Influence of nitrogen compounds and grape variety. Journal of Food Science 77:71-79. doi:10.1111/j.1750-3841.2011.02441.x.

Noguerol-Pato, R., Sieiro-Sampedro, T., González-Barreiro, C., Cancho-Grande, B., and Simal-Gándara, J. 2014. Effect on the aroma profile of Graciano and Tempranillo red wines of the application of two antifungal treatments onto vines. Molecules 19:12173-12193. doi:10.3390/molecules190812173.

OIV. 2003. Compendium of internationals methods of wine and must analysis. Organisation Internationale de la Vigne et du Vin (OIV), Paris, France.

Oshita, K., Kubota, M., Uchida, M., and Ono, M. 1995. Clarification of the relationship between fusel alcohol formation and amino acid assimilation by brewing yeast using 13C-labelled amino acid. p. 387-394. Proceedings European Brewery Convention, Brussels. Oxford University Press, Oxford, UK.

Pascual, G.A., Serra, I., Calderón-Orellana, A., Laurie, F., and Lopéz, M.D. 2017. Changes in concentration of volatile compounds in response to defoliation of Muscat of Alexandria grapevines grown under a traditional farming system. Chilean Journal of Agricultural Research 77:373-381. doi:10.4067/S0718-58392016000100001.

Peinado, R.A., Moreno, J., Bueno, J.E., Moreno, J.A., and Mauricio, J.C. 2004. Comparative study of aromatic compounds in two young white wines subjected to pre-fermentative cryomaceration. Food Chemistry 84:585-590. doi:10.1016/S03088146(03)00282-6.

Portu, J., González-Arenzana, L., Hermosín-Gutiérrez, I., Santamaría, P., and Garde-Cerdán, T. 2015. Phenylalanine and urea foliar applications to grapevine: Effect on wine phenolic content. Food Chemistry 180:55-63. doi:10.1016/j. foodchem.2015.02.008

Smit, I., Pfliehinger, M., Binner, A., Grossmann, M., Horst, W.J., and Löhnertz, O. 2014. Nitrogen fertilisation increases biogenicamines and amino acid concentrations in Vitis vinifera var. Riesling musts and wines. Journal of the Science of Food and Agriculture 94:2064-2072. doi:10.1002/jsfa.6525. 
Tao, Y., Li, H., Wang, H., and Zhang, L. 2008. Volatile compounds of young Cabernet Sauvignon red wine from Changli County (China). Journal of Food Composition and Analysis 21:689-694. doi:10.1016/j.jfca.2008.05.007.

Tea, I., Genter, T., Naulet, N., Lummerzheim, M., and Kleiber, D. 2007. Interaction between nitrogen and sulfur by foliar application and its effects on flour bread-making quality. Journal of the Science of Food and Agriculture 87:2853-2859. $10.1002 /$ jsfa.3044.

Torrea, D., Varela, C., Ugliano, M., Ancin-Azpilicueta, C., Leigh Francis, I., and Henschke, P.A. 2011. Comparison of inorganic and organic nitrogen supplementation of grape juice - Effect on volatile composition and aroma profile of a Chardonnay wine fermented with Saccharomyces cerevisiae yeast. Food Chemistry 127:1072-1083. doi:10.1016/j.foodchem.2011.01.092.

Ugliano, M., Kwiatkowski, M., Vidal, S., Capone, D., Siebert, T., Deval, J., et al. 2011. Evolution of 3-mercaptohexanol, hydrogen sulfide, and methyl mercaptan during bottle storage of Sauvignon blanc wines. Effect of glutathione, cooper, oxygen exposure, and closure-derived oxygen. Journal of Agricultural and Food Chemistry 59:2564-2572. doi:10.1021/jf1043585.

van Leeuwen, C., and Darriet, P. 2016. The impact of climate change on viticulture and wine quality. Journal of Wine Economics 11:150-167. doi:10.1017/jwe.2015.21.

Webster, D.R., Edwards, C.G., Spayd, S.E., Peterson, J.C., and Seymour, B.J. 1993. Influence of vineyard nitrogen fertilization on the concentrations of monoterpenes, higher alcohols, and esters in aged Riesling wines. American Journal of Enology and Viticulture 44:275-284.

Zhang, B., He, F., Zhou, P.P., Liu, Y., and Duan, C.Q. 2016. The color expression of copigmentation between malvidin-3-Oglucoside and three phenolic aldehydes in model solutions: The effects of pH and molar ratio. Food Chemistry 199:220-228. doi:10.1016/j.foodchem.2015.12.008. 